Tek, S. (2019). Irkçılık Karşıtı Sosyal Hizmet Uygulaması. Toplum ve Sosyal Hizmet, 30(3), 1142-1165.

Derleme

Makale Geliş Tarihi:20.02.2019

Makale Kabul Tarihi: 31.05.2019

\title{
IRKÇILIK KARŞITI SOSYAL HİZMET UYGULAMASI
}

\section{Anti-Racist Social Work Practice}

\section{Serhat TEK*}

*Dr., Hacettepe Üniversitesi, ORCID ID: 0000-0001-7140-2099

\section{ÖZET}

Sosyal hizmet, ayrımcılığın ve baskının her türlü formuna karşı doğal bir duruşa sahiptir. Tarihsel süreçten günümüze insanları yapay ayrımlarla birbirinden farkıllaştırmaya çalışan çeşitli 'ırk tespiti' çalışmaları yapılmıştır. Gücü elinde bulunduran gruplar tarafından kendi ekonomik ve yönetsel hedefleri için dayanak oluşturmak amacıyla çeşitli ırkların var olduğu savunularak, iddia edilen ırkların üyeleri için birtakım özellikler tanımlanmıştır. Söz konusu ırklara mensup bireyler sözde niteliklere göre 'aşağıda' veya 'yukarıda' konumlandırılarak ayırt edilmeye zorlanmıştır. Bu süreçte dünyanın farkı bölgelerinde pek çok insan ırkçılık sebebiyle baskı, zulüm, yaşadığı yerden zorla ayrılma ve ölümlere maruz bırakılmıştır. Bu durum ırkların olmadığı bir dünyada ırkçılığı ortaya çıkarmıştır. Irkçılık, sebepleri ve sonuçları ile günümüzde de varlığını sürdürmektedir. Bu çalışmada ırkçılık karşıtı sosyal hizmet uygulaması, ırk kavramı ve ırklar üzerine çalışmalar, ırkçılık, ırkçılığın boyutları kavramsal tartışması ışığında görünür kılınmaya çalışılmıştır. Çalışmada bir kurgusal vaka analizi ile ırkçılığın yıkıcı boyutlarının görülebileceği Hotel Ruanda filminin analizi gerçekleştirilmiştir. Bu yolla sosyal hizmetin ırkçılık karşıtı çalışmalardaki pozisyonunun somutlaştırılması hedeflenmiştir. Sonuç olarak çalışmada ırkçılık karşıtı sosyal hizmetin teoriden pratiğe; ırkçıık mağdurlarıyla çalışma, koruyucu- önleyici ve eğitsel çalışmalar, toplum çalışmaları, kültürel yetkinliğin vurgulanması, birey ve topluluk ile yönetsel erk arasındaki bağlantıların kurulması ve hak savunuculuğu anlamında çalışmalarını sürdüren bir uygulama boyutu olduğu vurgulanarak alana yönelik farkındalık oluşturulması amaçlanmıştır.

Anahtar Sözcükler: ırkçılık, ayrımcılık, baskı, ötekileştirilme, ırkçılık karşıtı sosyal hizmet, azınlıklarla sosyal hizmet

\section{ABSTRACT}

Social work has a natural stance against all forms of discrimination and oppression. Various 'race detection' studies have been conducted that try to differentiate people by artificial 
discrimination from the historical process of the present. Group that hold power have argued that there are various races in order to provide the basis of their economic and administrative goals. Therefore, a number of characteristics have been described for members of the claimed races. individuals belonging to the identified races were forced to be distinguished by being positioned 'below' or 'above according to the so-called qualifications. In this process, many people living in different parts of the world have been exposed to oppression, persecution, forced displacement and death due to racism. These situations have revealed racism in a world without races. Racism continues to exist today on its reasons and consequences. In this study, anti-racist social work practice is tried to be made visible in the light of conceptual discussions of race, studies on races, racism, dimensions of racism. In this study, a fictional case analysis and the analysis of the film Hotel Rwanda where the destructive dimensions of racism can be seen are analyzed. In this way, it is aimed to concretize the position of social work in anti-racist studies. As a result of this study, anti-racist social work is a practice that aimed to raise awareness and work in the sense of following topics from theory to practice: working with victims of racism, protective-preventive and educational studies, community studies, emphasizing cultural competence, establishing links between individual- community and administrative power, advocating rights.

Key Words: racism, discrimination, oppression, otherization, anti-racist social work, social work with minorities

\section{GíRiş}

"Irkçılık hala bizimle... Ancak, çocuklarımızı ne yapmaları gerektiği konusunda hazırlamak da bize kalmış ve umarız ki üstesinden geleceğiz.” Rosa Parks

Sosyal hizmet mesleği ve bilimi ilk dönemlerinde intiyaç halindeki dezavantajlı gruplara destek olarak başladığı yolculuğuna, sorun alanlarını çeşitlendirerek ve çalışmalarını da bu özel alanlara göre derinleştirerek uzmanlaşma yolunda ilerlemiştir. Sosyal hizmet, mesleki amaç ve değerleri açısından birey, grup ve topluma yönelik tüm önyargıları ve ön kabulleri reddeden bir yaklaşıma sahiptir (Kongar, 2007: 67). Bu bakış açısıyla alanda uygulamayı yürüten sosyal hizmet uzmanları müracaatçıların farklılıklarına odaklanmak yerine mesleki bir farkındalıkla, 'ötekileştirilmiş' bireylerin ve grupların hassasiyetleri konusunda gerekli önlemleri almak adına çalışmalar yürütür. Sosyal hizmet uzmanları ırk ve etnisite farklılıklarını, müdahalelerinin odağına alırken bu durumu ayrımcılığa yol açacak bir bakış açısıyla değil kültürel yetkinliğe dokunan yönüyle ele alır. 
Ayrımcılığın ve baskının her türlüsüne karşı doğal bir duruşu olan sosyal hizmet, gerek bilimsel gerekse de uygulama altyapısı anlamında çeşitli kuram ve teorilerden beslenmektedir. Irkçılık karşıtı sosyal hizmet uygulamasını kuramsal ve teorik anlamda destekleyen uygulama çerçeveleri şu şekilde sıralanabilir:

\begin{tabular}{|rl|}
\hline 1. & Ayrımcılık Karşıtı Sosyal Hizmet Uygulaması \\
\hline 2. & Baskı Karşıtı Sosyal Hizmet Uygulaması \\
\hline 3. & Hak Temelli Sosyal Hizmet Uygulaması \\
\hline 4. & Çokkültürcü Sosyal Hizmet Uygulaması \\
\hline 5. & Azınlıklarla Sosyal Hizmet Uygulaması \\
\hline 6. & Kültürel Açıdan Yetkin Sosyal Hizmet Uygulaması \\
\hline Çizelge.1
\end{tabular}

Ayrımcılık karşıtı sosyal hizmet uygulaması, ayrımcılığın farklı türlerini ele alan yapısıyla bir çatı uygulama çerçevesi olarak düşünülebilir. Ayrımcılığın bir türü ve tezahürü olan ırkçılık, ayrımcılıktan kaynaklanan ve ayrımcılığa neden olan bir yapıdadır. Bu sebeple ayrımcılık ve ırkçılık iç içe geçmiş kavramlar olarak değerlendirilmektedir (Thompson, 2006: 72). Baskı karşıtı sosyal hizmet uygulaması; nedeni ne olursa olsun her türlü baskının henüz ortaya çıkmadan engellenmesi adına çalışmalar yapan bir uygulama altyapısıdır. Sosyal hizmetin bu uygulama altyapısındaki rol ve sorumluluğu baskı mağdurlarının hak savunuculuğunu üstlenmek ve baskıya karşı güçlendirmeyi konumlandırmaktır (Laird, 2008: 20). Bu noktada hak temelli sosyal hizmet uygulaması da, ırkçılığın sebep olduğu eşitsizliğin negatif etkileri ile ırkçılığın bireysel, kurumsal ve yapısal nedenleri üzerinde çalışmalar yaparak söz konusu yapıyı ortadan kaldırmayı amaçlar (McPherson, 2015: 129). Irkçılığın karşısında konumlanan yapısıyla uygulamaya yön veren bir diğer çerçeve ise çokkültürcü sosyal hizmet uygulamasıdır. Bu uygulama çerçevesi bir toplumun birden fazla kültürden oluşabileceğini yani çokkültürlü bir yapıdan meydana gelebileceğini ancak bu durumun o toplumu çokkültürcü yapmaya yetmeyeceğini ifade etmektedir. Çokkültürcü bir toplumsal sistem, ülkede yaşayan tüm kültürlerin devletlerce sağlanan hak ve adalet temelli uygulamalar ile güvence altına alındığı bir yapıyı ifade eder. Dolayısıyla bu bakış açısı çokkültürlü olmanın yanında çokkültürcü olmanın önemine vurgu yapar (Özgür, 2014: 40-41). Azınlıklarla sosyal hizmet uygulaması ise farklı etnisite, dil, din, ulusal kimlik, cinsel yönelim ve cinsiyet kimliği sebebiyle bir toplum içerisinde azınlık olarak konumlandırılan toplulukların, başat toplumdan ayrılan yönlerinin ve haklarının savunulması anlamında sorumluluklar 
üstelenen bir uygulama altyapısıdır. Azınlık topluluklarına mensup birey, aile ve gruplarla çalışmalar yapan azınlıklarla sosyal hizmet uygulaması, azınlıkların kültürel özelliklerinin ve kimliklerin devam ettirilebilmesi açısından gerekirse pozitif statü haklarıyla desteklenmelerini, ayrımcılık ortadan kalkana kadar geçici özel önlemlerin alınmasını mesleki bir sorumluluk olarak takip eder ve üstlenir (Tek, 2018: 53). Son olarak kültürel açıdan yetkin bir sosyal hizmet uygulaması ise ırk temelli ayrımcılığın önüne geçmek açısından uygulamayı yürüten sosyal hizmet uzmanlarının çalıştıkları ülkede yaşayan kültürlerin farkında olması, söz konusu kültürlerin özellikleri ve hassasiyetleri hakkında bilgi sahibi olması gerektiğini belirtir (George-Bettisworth, 2017:10). Bu bağlamda, birbirinden beslenen ve birbirini besleyen yönleriyle yukarıda bahsi geçen tüm kuramsal çerçevelerin, ırkçılık karşıtı sosyal hizmet uygulamasına bilgi ve uygulama altyapısı bağlamında katkı sunan yönleri bulunmaktadır (Dominelli, 2017: 50).

\section{Irk Kavramı ve Irklar Üzerine Çalışmalar}

İnsanlara yönelik yapılan sınıflandırmalara ilk olarak M.Ö. 14. yüzyılda Antik Mısır'da rastlanılmaktadır. Antik Mısır'da yaygın olan mezar resimleri, günümüz sınıflandırmalarına temel teşkil edebilecek yapıda insanları fiziksel farklılıklarının açık şekilde görüleceği bir bakışla tasvir etmiştir. Bu tasvirle kuzeyde ve güneyde yaşayan insanlar net bir şekilde birbirinden ayırt edilebilmektedir (Marks, 2008: 22).

Traoré (2010: 4)'e göre, günümüzdeki anlamıyla ırk sınıflandırmalarının öncül çalışmalarını 17. yüzyılda François Bernier yapmıştır. Bernier, 1684 yılında yayınlanan 'Yeryüzünde Yaşayan Farklı Irk ve Türlere Göre Dünyanın Yeni Bölümleri' adlı çalışmasında insanları dört farklı gruba ayırmıştır. Sınıflandırma; yüz şekli, deri rengi, kafatası yapısı ve boyutu ile saç rengine göre yapılmıştır (Stuurman, 2000: 4). Bernier'in, fiziksel özellikler ve yaşanılan coğrafyaya göre belirlediği gruplar şu şekildedir:

1) Avrasyalılar (Eurasians)

2) Sahraaltı Siyah Afrikalılar (Sub-Saharan "Black" Africans)

3) Beyaz Doğulular (White Orientals)

4) Laponyalılar (Lapps) 


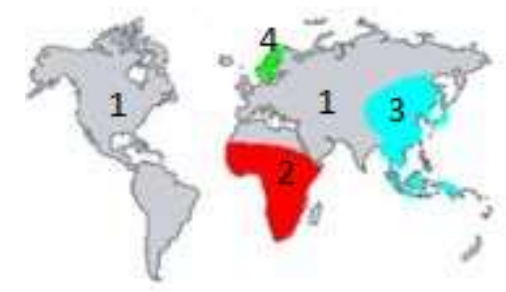

Şekil 1. Bernier'e Göre Irk Sınıflandırması (Rubies, 2013: 54).

Modern döneme yaklaştıkça ırklara yönelik çalışmaların, 18. yüzyılın son dönemlerinde tartışılmaya başlandığı ve 19. yüzyılda yoğun şekilde arttığı görülmektedir. Alman filozof Immanuel Kant'ın 'Çeşitli İnsan Irkları Üzerine' adlı makalesi 1775 'te yayımlanmıştır, Johann Friedrich Blumenbach'ın 'İnsan Türünün Doğal Çeşitleri Üzerine' başlıklı doktora tezi de aynı yıl Göttingen Georg August Üniversitesi Tıp Fakültesi'nde doktora tezi olarak kabul edilmiştir (Somersan 2012: 200).

Kıta Avrupası'nda sanayileşme sonrası ortaya çıkan güç ve pazar savaşları ile birlikte kolonileşme süreci başlamıştır. Kolonileşme faaliyetleri salt şekilde insanın değerini ayaklar altına alan bir süreci inşa ettiği gibi, eş zamanlı olarak da bu sürece haklı gerekçeler aramıştır. Bu arayışlar sonucunda, insanların aslında farklı ırklardan oluştuğunu savunan Kont Joseph Arthur de Gobineau'nun çalışmaları öne çıkmıştır (Hughes, 2012: 2). 1853-1855 yıllarında yayınlanan 'İnsan Irklarının Eşitsizliği Üzerine Denemeler' adlı eseri ile modern dönem ırkçılığının temellerini atan Gobineau'nun ırk sınıflandırması şu şekildedir:

1) Beyaz (Caucasian)

2) Siyah (Negroid)

3) Sarı (Mongoloid)

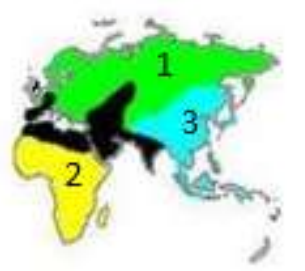

Şekil 2. Kont Joseph Arthur de Gobineau'ya Göre Irk Sınıflandırması (Lopez, 2000: 967-972).

İnsanları ırklara ayırmanın yanında her ırka ayrı özellikler atfeden Gobineau; beyaz ırkı üstün tutmuştur. Çalışmalarında genetik, psikolojik ve ahlaki açılardan beyazların 
üstünlüğüne vurguda bulunmuştur. Bu ayrıştırma insanları dış görünüşleri ile ayırmanın ötesinde, insanların türdeşlerine karşı sözde haklı gerekçelerle ayrım adı altında çeşitli baskılar, sömürüler, ötekileştirmeler uygulamasını meşrulaştırması ve kurumsallaştırması anlamında dikkatle üzerinde durulması gereken yapıdadır. Nitekim bu meşrulaştırma girişimleri, ırkçılığı yaygınlaştırma ve yapılan ayrımcılığı kurumsallaştırarak geçerli kılmayı amaçlamıştır (Giddens, 2008: 533).

Bernier ve Gobineau'nun çalışmalarında olduğu gibi ırk kavramını ele alırken ortaya konulan detaylandırılmış çalışmaların, süreci bilimselleştirme çabasından öte bir anlam taşımadığı düşünülmektedir. Nitekim ırk ayrımı temelinde çalışmalar ortaya koyan kişiler, insanları ortaklıkları yerine farklııkları üzerinden değerlendiren bir bakış açısıyla, yalnızca iddialarını savunmakla kalmayarak aynı zamanda görüşlerini mantıklı temellere oturtmayı amaç edinerek iddialarını geçerli kılmayı hedeflemektedir.

Yukarıda sözü edilen türde çalışmaların yanı sıra ırkların, ayrımcılığa temel olmayacak yönlerine atıf yapan çalışmalar da bulunmaktadır. Bu bağlamda Bulmer ve Solomos (1999: 7) ırk kavramını ele alırken üç temel noktayı ön plana çıkarmıştır.

- İnsanlar ortak birtakım özelliklerle farklı grupların üyesidir.

- Bu grupları oluşturan insanlar farklı kökenlere sahiptir.

- Irk temelli farklılıkların kültürel ve siyasi anlamları vardır.

Birleşmiş Milletler Eğitim, Bilim ve Kültür Örgütü (UNESCO) İkinci Dünya Savaşı sonrası ırkçılığın neden olduğu tabloyu görmüş ve bu konuda 'ırk' kavramı temelinde bir araştırma gerçekleştirmiştir. 1950, 1951, 1964 ve 1967 yıllarında yapılan araştırmalar sonucunda bir deklarasyon yayınlanmış ve ırk kavramı üzerine farklı açılardan açıklamalar yapılmıştır. Deklarasyon sonucunda ırk kavramının biyolojik bir kavram olmadığı, aksine sosyal bir mit olduğu ifade edilmiştir. İnsanların biyolojik ve sosyal açılardan ayrımlarının söz konusu olmadığı ve her iki kavramın ancak insanların bütünlüğü temelinde ele alınabileceği savunulmuştur (Banton, 1969: 18). Irk kavramı zamana, mekâna, ekonomik ve sosyal koşullara göre şekillenen yapay bir sürecin sonucu olarak ortaya çıkmıştır (Rattansi, 1994: 15).

Dolayısıyla ırk kavramının insanlar tarafından üretilen bir kategorileştirme aracı olduğu ifade edilebilir. Son yıllarda kavramın taşıdığı ayrıştıııcı nitelik sebebiyle akademik kullanımı azalmış ve söz konusu kavram yerine insanların kültürel 
farklılıklarına vurgu yapan etnik grup kavramı ön plana çıkmıştır (Büyükbay, 2016: 3). Canlıların sınıflandırıması anlamına gelen taksonomi hala bazı çevrelerce kabul görmekle birlikte, son yıllarda yapılan karşıt çalışmalarla insanların ırklar üzerinden sınıflandırıması görüşü yanlışlanmıştır. Günümüzde kabul gören görüş Homo sapiens sapiens yani modern insanın ırklara ayrılmadığı, tüm insan cinsinin tek bir alt türe yani Sapiens'e ait olduğudur. Bahsi geçen alt tür ve ırk tanımlarının temelinde yatan kanıt ise doğurganlıktır. Çünkü iddia edildiği gibi farklı alt türlerin olması durumunda, bu alt türlere ait üyeler çiftleşse bile yavrularının üreyemez halde dünyaya gelmesi gerekmektedir. Oysa insanlar için bu durum hiçbir şekilde geçerli değildir (Somersan, 2012: 200).

\section{Irkçılık}

Irk kavramının ortaya atılmasının temelinde insanların kendilerine yönelik özgeci bakışlarının ve kendilerini üstün görme eğilimlerinin olduğu ifade edilebilir. Doğrudan insanı temel alan, canlı-cansız tüm varlıklar içinde insanı özgeleştiren ve her şeyin insan için olduğunu iddia eden homosantrik görüşler ile insanı diğer insanlardan üstün olarak konumlandıran egosantik görüşler bu bakış açısının temelini oluşturmaktadır (Güvenç, 2016: 5). Bu fikri altyapı, var olduğu iddia edilen ırkları ortaya koymuştur. Irkları ortaya koymanın ötesinde insanların çeşitli yönlerden ayrıldığını varsayarak ırkçılığı meşrulaştırmayı amaç edinmiştir. Bilimsel tartışma zemininde ırkçılığın tam anlamıyla ne zaman ortaya çıktığı yönündeki iddialar iki önemli görüş temelinde sürdürülmektedir. İlk görüş, Antikçağda Eski Yunan ve Barbar kavimler arasındaki ayrımı ön plana koyarken, Hindistan'daki kast sistemine de atıf yaparak ırkçılığı tespit edilebilen ilk uygulamalarıyla ele almaktadır. İkinci görüş ise görece daha yakın bir döneme atıfta bulunarak ırkçılığın kapitalizm sonucu ortaya çıkan bir sömürü aracı olduğunu ifade etmektedir. Bu noktada kapitalizmin tarihsel ırkçılık uygulamalarını da temel alarak, sömürgeci ekonomik sisteme meşru bahaneler bulmak amacıyla işgalleri, köleleştirmeyi ve sömürge düzenini inşa ederek, ırkçılığı yapısal bir sistemle uygulamaya koymaya zemin hazırladığı belirtilmektedir (Özbek, 2012: 119-120).

Irkçılık, iddia edilen bir ırkın üyeleri için çeşitli özellikler tanımlayarak, söz konusu ırka mensup bireyleri tanımlanan sözde niteliklere göre aşağıda ve yukarıda konumlandırarak ayırt etmektir. Irkçılık, bir önyargılar ve yanlış inançlar bütünlemesidir (Hoyt Jr, 2012: 225). Irkçılık sömürgeci dünya düzeni tarafından oluşturulmuş içerisinde ataerki, modernizm, batı merkezli görüş, kaynak paylaşımı kavramlarını barındıran politik, kültürel ve ekonomik gerekçelerle yapay bir şekilde 
yeniden üretilmiş üstünlük ve aşağılık hiyerarşisi olarak tanımlanmaktadır (Grosfoguel, 2013: 74; Grosfoguel ve diğ., 2015: 636).

Irkçılığın, farklı biçimleri vardır. Dünyanın çeşitli bölgelerinde bulunan farklı sömürge geçmişlerine bağlı olarak, üstünlük ve aşağılık hiyerarşisi yapay olarak kurgulanmış çeşitli ırksal belirteçler yoluyla oluşturulmuştur. Irkçılık; renk, etnik yapı, ulusal yapı, dil, kültür veya din temelinde sürdürülebilir. Son yıllarda toplumsal cinsiyet, cinsel yönelim konuları da ayrımcılık temelinde ırkçılık konusu başlığı altında incelenir olmuştur (Grosfoguel, 2016: 10). Günümüzde ırkçılık kavramı, ilk dönemlere göre kapsam ve şekil bakımından farklılaşmıştır. Irkçılık, hâkimiyeti elinde bulunduran başat gruba mensup bireyler ile hükmedilen gruba mensup bireyler arasındaki ilişkiler şeklinde ortaya çıkmaktadır. Bir politika aracı olarak ırkçılık, daha çok baskı kurmanın bir yöntemi olarak görülmektedir (Sayın ve Candan, 2016: 37). Bu noktada ırkçılığın türleri, aktif ve pasif ırkçılık olarak değerlendirilmektedir. Aktif ırkçılık, gücü elinde bulunduran grubun ideolojisi çerçevesinde uygulamaya konulan politikalar olarak ifade edilmekteyken, pasif ırkçılık ise düşünce boyutunda bir grubu günah keçisi haline getirecek bir tutumu ön plana çıkarmaktadır (Somersan, 2009: 2).

\section{Irkçılığın Boyutları}

Irkçılık, sergilenen tutum ile ilişkili bir kavramdır. Irkçı ise bu tutumu düşünce, tavır ve davranışlarına yansıtan bireyi kavramsallaştıran bir ifadedir. Irkçılık, toplumsal boyutta karşıt olarak belirlenmiş olan bir diğer gruba yönelik açık veya örtük ırk temelli inançları ifade eder. Bu doğrultuda ırkçı ise var olduğuna inandığı bir ırka mensubiyeti sebebiyle bireyi ya da toplulukları, ait olduğunu düşündüğü ırktan aşağıda gören kişidir. Irkçılığın bireysel ve kurumsal boyutlarda sonuçları söz konusu olmaktadır. Bireysel anlamda ırkçılık, kayırmacı ve saldırgan edimlere dönüşebilen bir tutumken, kurumsal anlamda ırkçılık ise çoğunlukla yönetsel erk tarafından sistemli olarak hayata geçirilen ayrımcı tutumlar olarak karşımıza çıkmaktadır (Giddens, 2008: 540541). Irkçıığın kurumsal boyutu, ırkçılığı sistemli olarak devletin bir politikası olarak eyleme dönüştürmenin yanında, inceden inceye ırkçıığı meşrulaştıran bir yapı ortaya koymaktadır. Bu durum da döngüsel bir nedensellikle kurumsal ırkçılığın, bireysel ırkçılığa dönüşmesine sebebiyet vermektedir (Brockmann ve diğ., 2001: 1).

Büyükbay (2016), ırkçılığın boyutlarını açıklarken güç, grupların kutuplaşması, doğal ayrımlar ve kültürel farklııklar kavramlarından söz etmiştir. Güç; baskı ve itaati temellendiren kavram olarak başat pozisyonda yer almaktadır. Bu durum eşitsiz bir ilişkiler bütünü oluşturarak grupların karşıt hale gelmesini ve uca savrulmasını 
tetikleyerek grupları kutuplaştırır. Gruplar arasında doğal olarak farklılıklar meydana gelir. Böylelikle, taraflar arasında pek çok anlamda derinleşen farklılıklar, bir kültüre dönüşerek kanıksanmaya başlanır. Sonuç olarak taraflar arasındaki ayrımların doğal bir süreç sonucu ortaya çıkan yapılar olduğuna inanılır. Bu durum da sürecin yapısal hale gelerek ırkçılığın doğal ve değişmez olarak kabul edilmesine neden olabilir.

Irkçılığın boyutları dönemin ve siyasi konjonktürün değişimiyle birlikte yeni formlara evrilerek değişiklik göstermektedir. Örneğin; ırkçılığın ilk olarak ele alındığı dönemlerde biyolojik ırkçılık boyutu öne çıkarken, sonraki dönemlerde salt bir karşı duruşa sebep olan bu ırkçılık türü dönüşüm yaşamıştır. Biyolojik ırkçılık yerini üstünlük fikrini temel alan ırkçılığa bırakmıştır. Bu ırkçılık boyutu 'yeni ırkçılık (neo racism)' adı verilen bir dönemi başlatmıştır. Yeni ırkçılık görüşü kültürel boyutta, ırkçılığı kodlarla sistematize eden bir alt ve üst tabaka yaratmayı amaç edinmiştir. Bu ırkçılık anlayışı çeşitli görsel kodlara anlamlar yükleyerek bireyleri yaşam tarzlarına göre kimliklere ayırmakta, bu yolla politize ederek ayrıştırmaktadır (Sayın ve Candan, 2016: 37). Küreselleşme ile yeni ırkçılığın günümüzde gözle görünür şekilde yaşamımızda var olduğu ifade edilmektedir. Özellikle kapitalist ekonomi sisteminin planlanan hedeflere ulaşması adına toplumun bir kısmını işgücü olarak istihdam etmek isteyeceğini, diğer kısmını ise sistemin yürütücüsü olarak işveren pozisyonunda değerlendirmeyi amaçladığı belirtilmektedir. Söz konusu ekonomik sistemin bu yolla biyolojik temelli ırkçılık yerine kültürel ayrım temelli yeni ırkçılık kavramını teorileştirdiği ifade edilmektedir (Aronson ve diğ., 2012: 803). Yeni ırkçılık kavramının küresel boyutta ekonomik hedeflerine örnek olarak Amerikan şirketlerinin Asyalıları ucuz işgücü olarak istihdam etmesi gösterilebilir. Bu durum yeni ve yükselen yönüyle ırkçılığı konumlandırmakta ve siteme uygun olarak 'model azınlıklar' üretmektedir (Chou, 2008: 219).

Dünya üzerinde pek çok ülke kendi varlığını inşa edebilmek adına ötekileştirmeyi, ayrımcılığı ve ırkçılığı birer strateji olarak kullanmıştır ve hâlihazırda kullanmaktadır. Bu duruma örnek olarak, ırk kavramının etkisinin tüm yıkıcı boyutlarıyla görüldüğü 20. yüzyılın ikinci çeyreğinde kendi ulusal ideolojileri adına birçok insanı öldüren Alman nasyonal sosyalizmi verilebilir. Bu süreçte Adolf Hitler yönetimindeki nasyonal sosyalizm hareketi, yaklaşık 6 milyon Yahudi'yi ve toplamda sayıları 5 milyonu bulan Romanlar, Slav halkları, Yehova şahitleri, siyahlar, eşcinseller, fiziksel ve zihinsel engelliler, komünistler, sosyal demokratlar, siyasi muhalifler, din adamları, direnenler, savaş esirleri ve sanatçıları katletmiştir (Friedman, 1995). Hitler, üstün -ari- bir ırk 
yaratmayı amaç edinmiş, bu sebeple de ırkçı idealine engel olabilecek olan tüm 'öteki'leri ortadan kaldırmakta herhangi bir sakınca görmemiştir.

Buradan hareketle, ırk ve ırkçılık kavramları yapay birer kurgudan ibaret olduğu halde geçmişten günümüze değişen boyutlarıyla varlığını sürdürmüş ve insanlık adına üzücü deneyimlere sebebiyet vermiştir. Irkçılık katliama varan boyutlarıyla günümüzde de sürdürülmeye çalışılan bir ayrımcılık biçimidir. Irkçılığın insanların yaşam hakkı gibi temel haklarını tehdit eden boyutlara ulaşması, insani bilimlerin kavramın etkisi ve yıkıcılığı üzerine çalışmalar gerçekleştirmesinin gerekliliğini ispatlar niteliktedir.

\section{Irkçılık Karşıtı Sosyal Hizmet Uygulaması}

Sosyal hizmet, çalışmalarının odağına insanı ve insanın değerini konumlandırır. Irkçılık gibi insan haklarını ihlal eden fikirleri ve kabulleri kökten reddeder. Bu açıdan sosyal hizmet, gerek teori gerekse de uygulama boyutunda doğası gereği ırkçılık karşıtı bir duruşa sahiptir. Irkçılık karşıtı sosyal hizmet, sosyal hizmetin bir meslek olarak uygulandığı ilk zamanlardan itibaren fikri altyapı olarak sosyal hizmet çalışmalarında var olmuştur. Ancak alanda bilimsel anlamda tam olarak karşılığını ancak 1970'lerden sonra radikal görüşün gelişimiyle alabilmiştir (Wainwright, 2009: 498). Irkçılık karşıtı sosyal hizmet ilk zamanlarda beyaz-siyah ayrımı temelli bir uygulamadan yola çıksa da, günümüzde kurgulanan ırk düşüncesi üzerinden biçimlenen tüm ayrımcılık türleri bu kapsama dahil edilmektedir. Irkçılık karşıtı sosyal hizmet, belli bir dönem yaygın olan beyazlığı ve beyazların kültürünü üstün olarak gören görüşü kesin bir dille reddeder (Butler ve diğ., 2003: 275).

Irkçılık karşıtlığını odağa alan yönüyle ayrımcılık karşıtı sosyal hizmet, ırkçılı̆ı hem bireysel anlamda hem de kurumsal anlamda reddeder. Ayrımcılık karşıtı sosyal hizmetin politika ve yasalar, teori ve uygulama, eğitim ve öğretim gibi alanlarda katkı ve kazanımlarından bahsedilmektedir (Keating, 2000: 79). Bu bakış açısı ile ırkçılık karşıtı uygulama, sosyal hizmetlerin planlanmasının ve sunumunun yalnızca hakim olan grubun bakışı ile şekillenmesinin önüne geçen, azınlık ve etnik grupları da bu sürece dahil eden bir yapının gerekliliğine dikkat çekmektedir.

Yukarıda da ifade edildiği üzere, ırkçılık karşıtı uygulamalar ilk olarak beyazların üstünlüğünü savunan görüşlere ve beyazlık algısına yönelik bir tepki olarak ortaya çıkmıştır. Bu tepkinin temelinde beyazların üstünlüğünün savunulması kadar, sosyal intiyaçların ve hizmetlerin beyazları temel alan bir bakış açısıyla sunulmasının da 
etkisi vardır. Bu açıdan bakıldığında çeşitli ülkelerde sağlık, refah ve güvenlik hizmetlerinde ırkçı bir hizmet yapısı görmek mümkündür (De Montigny, 2013: 634). Bir diğer açıdan konuya yaklaşıldığında ise Avrupa'da sosyal hizmet uygulamalarının çoğunlukla beyaz sosyal hizmet uzmanları tarafından gerçekleştirildiği görülmektedir. Eliassi (2017: 31) tarafından yapılan çalışmaya göre, beyaz sosyal hizmet uzmanlarının kültürel yetkinlikle bağlantılı olarak, dünyanın farklı ülkelerinden gelen göçmenlere yönelik kapsamlı bir bilgi altyapısına sahip olmadıkları, dolayısıyla bu anlamda sosyal hizmet politikalarının bunu güvence altına almasının gerekliliğinin altı çizilmiştir. Bu anlamda Avrupa'ya gelen göçmenlere yönelik sosyal hizmetler sunulurken dil, görünüş, din, tarih vb. hassasiyetlere yönelik sosyal hizmet uzmanlarının farkındalık gelişimine intiyacı olduğu ifade edilmiştir. Sosyal hizmet uzmanlarının 'renk körü' profesyoneller olmamaları, ırkçılık karşıtı sosyal hizmet uygulaması açısından en önemli nokta olarak görülmektedir (Loya, 2011: 203). Bir diğer araştırmada, Wainwright (2009: 502) siyah sosyal hizmet uzmanlarının siyahlara yönelik sosyal hizmet uygulamasında yeni bir ırkçılığa zemin vermeden başarılı çalışmalar gerçekleştirdiğini ortaya koymuştur. Bu durum ırkçılık ve ayrımcılık tam olarak ortadan kaldııııncaya kadar alınması gereken geçici özel önlemler kapsamında değerlendirilmelidir. Desai ve Gooden (1995: 219) ise çalışmalarında ırkçılığın; toplumsal cinsiyet, sosyal sınıf, tek ebeveynli olma durumu gibi durumlar ile birlikte olduğunda etkilerinin daha da artabildiğini ortaya koymuştur. Bu bağlamda araştırmada, sosyal hizmet uzmanlarının siyah aileler örneğinde güçlendirme ve pozitif bir bakışla çözüm adına ırkçılık karşıtı ve çokkültürcü bir yolu mümkün hale getirebileceklerinden bahsedilmiştir.

Amerikan Sağlık İşgücü Merkezi Çalışmaları (CHWS) ve Amerikan Ulusal Sosyal Hizmet Uzmanları Birliği (NASW)'ın 2006 yılında yapmış oldukları bir çalışmaya göre, Amerikan nüfusunun \%68'i beyazlardan oluşmaktadır. Sosyal hizmet alanında çalışan meslek elemanları açısından değerlendirildiğinde ise kendisini beyaz olarak tanımlayan lisanslı meslek elemanlarının toplam oranı \%85, siyah meslek elemanlarının oranı \%7, Hispanik ve Latin meslek elemanlarının oranı \%4, Asyalıların oranı \%1, Amerikan Yerlilerinin oranı ise \%1'dir. Sosyal hizmetlerden yararlanan müracaatçıların oranlarına bakıldığında ise araştırmada yer alan sosyal hizmet uzmanlarının \%85'i siyah, \%77'si Hispanik ve Latin, \%49'u Asyalı, \%39'u Amerikan Yerlisi müracaatçılarla çalıştıklarını belirtmiştir. Araştırma verilerinden hareketle sosyal hizmet uzmanları, büyük bir oranla etnik azınlık gruplarıyla çalışmaktadır (CHWS ve NASW, 2006). Amerika Birleşik Devletleri 20. yüzyılın üçüncü çeyreğine 
kadar ulusal politikalar ve uygulamalar bağlamında ırkçılık tabanlı ayrımcılığın örneklerine sahne olmuş bir ülkedir. Bu bilgiler doğrultusunda sosyal hizmet uzmanlarının alanda ve akademik bağlamda yürüttükleri çalışmaların gizil ya da açık olarak ırkçılıktan korunması, ancak sosyal hizmet uzmanlarının farklılığa ilişkin bilgi ve becerilerini artırmaları ile gerçekleşebilir. ABD örneğinde sosyal hizmet uzmanlarına düşen en önemli görevin yakın zamana kadar kamusal bağlamda ırkçılığın var olduğu, günümüzde ise toplum bazında ırkçılığa yönelik eylemlerin sıklıkla görüldüğü bir ortamda azınlıkların ve farklılıkların farkında bir hizmet sunmak ve söz konusu grupların savunuculuğunu üstlenmek olduğu söylenebilir (Loya, 2011: 205). Brockmann ve diğ., (2001: 1) ise çalışmalarında siyah ve etnik açıdan farklı sosyal hizmet uzmanlarının ırkçılığa maruz kaldıklarından söz etmektedir. Söz konusu çalışmada ırkçılığın sosyal hizmet uzmanlarını bütüncül açıdan etkilediğinden bahsedilerek, bu negatif etkiye karşın sosyal hizmet uzmanlarının deneyim, algı ve baş etme stratejileri geliştirdikleri ifade edilmiştir.

Sosyal hizmet uzmanları değişen boyutlarda ırkçılık ve ayrımcılığa maruz kalabilmekte ve bir takım yanlış uygulamalarla ırkçılık ve ayrımcılığın uygulayıcısı konumuna gelebilmektedir. Bu noktada Türkiye örneğine bakıldığında ise Acar ve diğ., (2017: 44) yaptıkları çalışmada sosyal hizmet uzmanlarının ayrımcılık ve etiketlemenin pek çok görünümüyle ilişkili olduğunu ifade etmektedir. Çalışmaya göre, yaş, cinsiyet, etnisite, inanç, cinsel yönelim, engel durumu gibi bir takım farklııklar sebebiyle sosyal hizmet uzmanları hem ayrımcılığa uğrayabilmekte hem de ayrımcılığı uygulayan taraf olabilmektedir.

Görüldüğü üzere, ırkların olmadığı bir dünyada ırkçılık her ortamda ve her düzeyden birey ve topluluğu tehdit eden yapısıyla varlığını sürdürmektedir. Acar ve diğ., (2017: 44-47)'a göre sosyal hizmet, herkes için hak temelli ve eşitlik ilkesine dayanan hizmetlerin sunulmasının sağlanması için çalışır. Bu noktada sosyal hizmetin ırkçılık ile mücadelede çeşitli rol ve sorumlukları söz konusudur. Graham (2000: 425) ırkçılık karşıtı sosyal hizmetin etik perspektiften temel prensiplerini ve sosyal hizmet uzmanlarının alana ilişkin rollerini aşağıdaki şekilde sıralamıştır;

- Irkçılık karşıtı sosyal hizmet, ideolojik toplumsal yapının tanımladığı ırk kavramının sosyal ve politik anlamlarıyla bir ırkın diğer ırklardan üstün olduğu fikrini ifade ettiğinin farkındadır.

- Irkçılık karşıtı sosyal hizmet, ırkçılığın sosyal yaşam, barınma, iş ve eğitim alanlarında sosyal etkilerinin olduğunu bilir. 
- Irkçılık karşıtı sosyal hizmet, sosyal baskının diğer tüm formlarını incelemeden ırkçılığın sosyal etkilerine yönelik incelemelerin eksik kalacağını bilir.

- Irkçılık karşıtı sosyal hizmet uzmanları, kendi bireysel yanlılıklarının, davranışlarının ve kalıp yargılarının farkındadır. Bu durumlarla baş etme ya da mesleki yönlendirme yapma zorunluluğu olduğunun bilincindedir.

- Irkçılık karşıtı sosyal hizmet uzmanları, ırka dayalı sosyal yapının ırkçılık temelli bir görüş olduğunu bilir ve sosyal değişimin ancak ırkçılık karşıtı bir uygulamayla gerçekleşeceğinin farkındadır.

- Irkçılık karşıtı sosyal hizmet uzmanları, kurumsal ırkçılığın önüne geçer ve siyah ya da azınlık mensubu diğer topluluklardan bireylerin kurumsal temsiliyetine yönelik sosyal kontrolü ve savunuculuğu üstlenir.

\section{Örnek Vaka: Nadia W.}

Albert W. (1900 doğumlu), 1941 yılının ağustos ayında, Potsdam Almanya'da çalıştığı enstitüden ayrılarak Türkiye'ye gelen Yahudi bir tıp profesörüdür. Prof. W., eşi Yasmine W. (1903 doğumlu) ve kızı Nadia W. (1938 doğumlu) ile birlikte Ankara'ya yerleşmiştir. Prof. W., uzmanı olduğu kürsünün Ankara'daki bir üniversitede kurulmasına öncülük etmiştir. Ankaralı Yahudilerle kısa zamanda yakın ilişkiler kuran aile, ibadetlerini Ulus Anafartalar'daki 800 yıllık Tarihi Sinagog'da sürdürmeye başlamıştır. W. ailesi Cebeci semtinde ikamet ettiği için, kızları Nadia W. Cebeci'deki devlet okullarında ilk ve ortaöğrenimini tamamladıktan sonra, Devlet Konservatuvarı Şan Bölümüne girmiştir. Nadia W. üniversiteden mezun olduktan sonra kendi bölümünde akademisyen olarak çalışmaya başlamıştır. Nadia W.'nin gençlik döneminde romantik ilişkileri olmuş ancak evlilikle sonuçlanan bir ilişkisi olmamıştır. Anne ve babasın 1965 yılında bir trafik kazası sonucu kaybeden Nadia W., olaydan sonra tek başına yaşamını sürdürmüştür. 32 yıl çalıştıktan sonra 1995 yılında emekli olmuş, yazları Bodrum'daki yazlığında, kışları ise Ankara'da ikamet etmiştir.

Gençlik yıllarından itibaren sigara içen Nadia W. rutin sağılı kontrolleri için hastaneye gittiği sırada nefes darlığından şikâyette bulunmuş, yapılan tetkikler neticesinde koah hastası olduğunu öğrenmiştir. Bu hastalıktan dolayı sigarayı acilen bırakması gerektiğini öğrenmiş ve rutubetli ortamlardan, üzüntü ve stresten uzak durması gerektiği konusunda doktoru tarafından uyarılmıştır. 2018 yılına kadar sigara alışkanlığını bırakmayan ve doktorunun tavsiyelerine uymayan Nadia W., bir gün merdiven çıkarken ani nefes darlığı yaşamış, kalbinin zorlandığını hissetmiş 
apartmanda yığıııp kalmıştır, sesleri duyan komşuları tarafından hastaneye kaldırımıştır. Acil servise kaldııılıktan sonra iç hastalıkları servisine yatışı gerçekleştirilmiştir. Yapılan incelemeler sonucunda hastalığının akciğer kanserine evrildiği öğrenilmiştir. Yaklaşık 2 ay hastanede tedavi gören Nadia W. bu süreçte Sosyal hizmet uzmanı Mahir İ. tarafından rutin bir şekilde ziyaret edilmiştir. SHU Mahir I. gerçekleştirdiği görüşmeler ve yaptığı araştırmalar sonucu taburculuğu yaklaşan Nadia W.'nin tek başına bakımını sürdürmesinin zor olacağı kanısına varmıştır. Bu görüşünü hastanedeki paydaş tıbbi tedavi ekibiyle de paylaşmış, onların da desteğini almıştır. SHU Mahir İ. öncelikle huzurevi fikri konusunda Nadia W.'yi bilgilendirmesi gerektiğini düşünmüş, bu konuda araştırma yapmış, huzurevleri ile bağlantıya geçmiştir. Ayrıca Nadia W. İle iletişim halinde olan komşularından ve arkadaşlarından da süreç boyunca destek almıştır. U. Huzurevinde bir kişilik kontenjan açıldığını ve ellerini çabuk tutmaları gerektiğini öğrenen SHU Mahir İ. süreci hızlandırmıştır. Nadia W. ilk olarak SHU Mahir l'ye karşı çıkmış, ancak doktorların ve yakınlarının telkinleriyle huzurevine gitmeyi kabul etmiştir. Bunun üzerine SHU Mahir İ, huzurevinde görevli SHU Gülşen K. ile görüşme gerçekleştirmiş ve Nadia W. hakkında bilgi vermiştir.

Huzurevine kabulü gerçekleştirilen Nadia W. iki kişilik bir odaya yerleştirilmiştir. Odasında birlikte kaldığı Behiye Ş.; 67 yaşında, okuma yazması olmayan, huzurevine gelene kadarki yaşamının tamamını köyünde geçirmiş, üç çocuğu olan bir kadındır. Behiye Ş., Nadia W. ile tanıştığında ilk olarak nereli olduğunu ve adının neden Nadia olduğunu sormuştur. Bunun üzerine Nadia W., Ankaralı bir Yahudi olduğunu söylemiştir. Nadia W. ilk üç gün odasından yemek saatleri dışında çıkmamış ve Behiye Ş. ile de sınırlı iletişim kurmuştur. Bu durum huzurevinde görevli SHU Gülşen K.'nın dikkatini çekmiş ve Nadia W. ile görüşmeye karar vermiştir. Yaptığı görüşme neticesinde huzurevinde çeşitli etkinlikler olduğundan bahsetmiş ve Nadia W.'nin odasından çıkması için onu güçlendirmiştir. Bu görüşme üzerine Nadia W. ertesi gün kahvaltı sonrasında huzurevindeki oturma bölümüne gitmiş ve gider gitmez, kendisini tanıtmasına fırsat verilmeden, Yahudi kimliği üzerinden söylemlere maruz kalmıştır. Nadia W. onlara kimliği hakkındaki bilgiyi Behiye Ş.'nin verdiğini düşünmüş ve bu konu hakkında konuşmak istemediğini dile getirmiştir. Oturma salonunda oturan üç erkek yaşlı, Nadia W.'ye "Yahudiliğin ve gavurluğun kötü bir şey olduğunu" , "Yahudilerin Müslümanları katlettiğini", "Hitler'in aslında Yahudilerin tamamını öldürmediği için suçlu olduğunu" söylemiştir. Bu durum karşısında Nadia W. gözyaşlarına hakim olamamış ve hızlı bir şekilde odasına gitmiştir. Yaşananları 
öğrenen SHU Gülşen K. ne yapacağını bilememiş ve kuruluşta görevli diğer sosyal hizmet uzmanlarıyla acil bir toplantı yapması gerektiğini düşünmüştür. Siz bahsi geçen kuruluşta görevli bir sosyal hizmet uzmanı olsaydınız, bu durum karşısında;

1. Bu vakada müracaatçı ile çalışmanızı güçleştirebilecek ön yargılarınız ve ön kabullerinizin olup olmadığını sorgular mıydınız?

2. Kendi kültürel yetkinliğinizi gözden geçirerek bilgi edinme ya da bilgilerinizi güncelleme ihtiyacı duyar mıydınız?

3. Vakada bahsi geçen Türkiye Yahudi topluluğunun kendilerine ait yaşlı bakım hizmetleri olup olmadığını araştırır mıydınız?

4. Bu vaka özelinde hangi sosyal hizmet kuram ve yaklaşımlarından faydalanırdınız?

5. Bu vakanın çözümü adına sosyal hizmet uzmanının hangi rol ve işlevlerini kullanırdınız?

6. Bu tür bir sorunla karşılaştığınızda "müracaatçının biricikliği ve değeri" konusunda ne tür bir yaklaşım sergilerdiniz?

7. Bu vaka özelinde ve benzer vakalar genelinde nasıl bir tavır sergilerdiniz?

8. Bütüncül bir çözüm adına nasıl bir sosyal hizmet müdahale planı yapardınız?

\section{Örnek Vaka Analizi}

Bu bölümde yukarıda verilen sorular üzerinden vaka analizi gerçekleştirilecektir.

1. Sosyal hizmet uzmanlarının öz farkındalığının yüksek olması önemlidir. Her birey gibi bizlerin de yetiştiği çevresel koşullar, sosyal faktörler, inanç sistemi, tarihi süreçler vs. sebeplerle belirli birey, grup ve topluluklara yönelik ön yargılarımız ve ön kabullerimiz olabilir. Asıl olan profesyonel meslek elemanları olarak uygulamamıza bu durumu yansıtmamamızdır. Şayet uzmanlığımızın yetmeyeceğini düşünüyorsak bu durumda ise müracaatçının yüksek yararını düşünerek müracaatçıyı alanında uzman başka bir meslektaşımıza yönlendirme sorumluluğumuz olduğunu da unutmamalıyız.

2. Sosyal hizmet uzmanı, kültürel açıdan yetkin olmalıdır. Öncelikle bulunduğu ülkede yaşayan topluluklardan başlamak üzere, çalışması muhtemel tüm birey ve grupların hassasiyetleri ile ilgili temel düzeyde de olsa bilgi sahibi olması gerekmektedir. Hakkında az bilgi sahibi olduğumuzu düşündüğümüz bir topluluğa mensup müracaatçı ile çalışmamız gerektiğinde öncelikle bilgi dağarcığımızı güncellememiz gerektiğini bilmek durumundayız. 
3. Türkiye'de yaşayan ve azınlık olarak ifade edilen Ermeni, Rum, Yahudi, Süryani ve Bulgar topluluklarının kendilerine ve genele hizmet veren sosyal hizmet kuruluşları bulunmaktadır ve az sayıda da olsa bu kurumlarda çalışan meslektaşlarımız bulunmaktadır. Dolayısıyla müracaatçının talebi ve yüksek yararı doğrultusunda ilgili sosyal hizmet kuruluşları ile bağlantı kurmanın mesleki rol ve sorumluluklarımızdan olduğunu aklımızda bulundurmalıyız.

4. Bu vaka özelinde müracaatçının bulunduğu yaşam koşullarının, çevrenin ve aile ortamının odak sistemle olan ilişkisi bakımından sistem ve ekosistem, sağlık ve huzurevi hizmetlerinden yararlanması ve haklarının temini bağlamında hak temelli uygulama, müracaatçının sağlık koşullarına ve yeni yaşam ortamına alışması bağlamında güçlendirme yaklaşımı, müracaatçının destek sistemlerinin harekete geçirilmesi bağlamında güçler perspektifi ve ırkçılık, ayrımcılık, baskı ve ötekileştirilmeye karşın baskı karşıtı uygulama, ayrımcılık karşıtı uygulama, ırkçıık karşıtı uygulama, çokkültürcü sosyal hizmet ve azınlıklarla sosyal hizmet kuram, yaklaşım ve bilgi altyapılarından faydalanılması işlevsel olacaktır.

5. Bu vakada sosyal hizmet uzmanının müracaatçının haklarının savunulması ve takibi bağlamında savunuculuk rolü, diğer kuruluşlarla ve meslektaşlarla irtibat ve etkileşim halinde olması hususunda bağlantı kurucu rolü, müracaatçının psiko-sosyal açıdan değerlendirilmesi ve müracaatçıya gerekli bilgilerin sağlanması noktasında danışmanlık rolü, uygulamanın bütüncül bakış açısıyla değerlendirilmesi hususunda vaka yöneticisi rolü bulunmaktadır.

6. Vakadaki örnekte yer verilen müracaatçı gibi dezavantajlı ve geçici özel önlem kapsamında desteklenmesi gereken bireyler sosyal hizmet uzmanlarının öncelikli değerlendirmesi gereken müracaatçılardandır. Bu tür müracaatçıların hassasiyetlerinin korunması ve temini sosyal hizmet uzmanlarının rol ve sorumlulukları kapsamındadır. Etik açıdan, vaka ve empati-sempati dengesini koruyarak müracaatçıların değeri üzerinde özenle durulması gerekmektedir.

7. Bu tür vakalarda sosyal hizmet uzmanının tutum ve yaklaşımı profesyonel bir bakış açısıyla sunulmalıdır. Sıklıkla karşılaşmadığımız müracaatçı grupları hakkında zamanımız var ise ivedilikle bilgi edinmek, yeterli zamanımız yok ise incitici olabileceğini düşündüğümüz herhangi bir eylem ve söylemden uzak durarak müracaatçıya yönelik azami saygıyı göstermeli ve gerekirse süpervizyona başvurarak profesyonel destek sistemlerimizi harekete geçirmeliyiz. 
8. Müracaatçının sorunlarının çözümü ve yüksek yararının temini adına 7 aşamalı müdahale planını dördüncü maddede ifade edilen vakaya özel dikkate alınması gereken kuram, uygulama ve bilgi alt yapılarından yararlanarak; öncelikle müracaatçı ile tanışma, müracaatçının durumunu değerlendirme, müracaatçının talepleri ve öncelikleri doğrultusunda bir müdahale planı hazırlama, birlikte hazırlanan planı uygulama, uygulamayı takiben gerçekleştirilen genel değerlendirme, süreci sonlandırma ve takip aşamaları ile bütüncül bir değerlendirme ile sürdürmeliyiz.

\section{Örnek Film: Hotel Ruanda}

Film 1990'lı yılların başında Afrika'da bulunan Ruanda'da yaşayan Hutu'lar ve Tutsi'ler arasındaki iç savaşı işlemektedir. Aslında aralarında hiçbir fark olmayan söz konusu iki grubun üyeleri, yıllarca bölgeyi sömüren Belçika'nın ve Fransa'nın politikaları sonucunda suni ayrımlarla birbirinden ayrıştırılmıştır. Belçikalılar ve Fransızlar belli dönemlerde Hutu'ları, belli dönemlerde Tutsi'leri desteklemişlerdir. Aynı bölgede yaşayan insanlar sadece ten rengi (Hutu'ların teni daha koyu, Tutsi'lerin daha açık), kilo-boy, burun yapısı vb. farklılıkları sebebiyle birbirinden farkılıştırılmış ve iki ayrı ırk ortaya çıkarılmıştır. Bu iki ırkın üyeleri zaman içerisinde gözünü kırpmadan birbirini öldürebilen gözü dönmüş hasımlara dönüştürülmüştür.

Ruanda'da süreç boyunca 1 milyona yakın insan can vermiştir. Film, başrolde yer alan Paul Rusesabagina ve ailesinin etrafında örüntülenmektedir. Yaşanan hadiseler Paul ve yakın çevresindeki insanların yaşamı üzerinden tüm Ruanda'da yaşayan insanların ne denli acılar çektiğine dikkat çekmektedir. Paul karakteri, yaşanan tüm ayrımlara rağmen hiçbir zaman kendini düşünmeyen, her zaman kendini Hutu-Tutsi ırk ayrımından uzak konumlandırmış bir birey profili çizmektedir. Kendisi Hutu olduğu halde, Tutsi'lere yardım edebilme erdemini gösterebilmiş ve kaçınılmaz son olan 'vatan hainliği' ile suçlanmayı göze almıştır. Paul, süreç boyunca 1268 insanın hayatını kendi canı pahasına koruyarak onların kurtulmasını sağlamıştır.

Paul süreç boyunca ülkesinde yaşananlara sessiz kalan batılı güçlere yönelik şu sözleri sarf etmiştir: "büyük ülkeler soykırıma seyirci kaldılar; çünkü bizim topraklarımızda altınımız ve elmasımız yoktu. Sadece kahve ve çay üretebiliyorduk.". Filmde dikkat çeken bir diğer nokta ise bölgedeki Birleşmiş Milletler kuvvetlerinin katliamı durdurmak için hiçbir şey yapmaması, Ruandalıları bırakarak sadece ülkede bulunan çoğunluğu beyaz olan yabancıları alarak ülkeyi terk etmeleridir. Yabancıların 
otelden ayrıldığı sahnede, yabancılar dışında hiç kimsenin otobüslere alınmaması buna karşın otobüsün içinden dışarı bakanlar arasında bir yabancılara ait olan bir süs köpeğinin olması dikkat çekicidir. Bir diğer sahnede ise özellikle çatışmanın başladığı süreçte Birleşmiş Milletler askerleri ülkeden ayrılırken, otel müdürü olan Paul'un bir gazeteci ile gerçekleştirdiği şu konuşma dikkat çekicidir:

-Paul: "Bütün bu olanları dünyaya gösterin, Ruanda'daki bu vahşeti ki bize yardım etsinler. Kimse buna tepkisiz kalamaz" der.

-Gazeteci: "Evet tepkisiz kalmayacaklar, akşam yemeklerini yerken ana haber bülteninde izleyecekler bu görüntüleri, sizin için üzülecekler ve daha sonra yemeklerine devam edecekler ve günlerinin nasıl geçtiğini konuşacaklar" der.

Bu sözler Ruanda Soykırımına yönelik Batılı ülkelerin bakış açısını ifade eden önemli bir gönderme niteliğindedir. Bu her iki alıntı da göstermektedir ki, yaşanan katliamlar her ne kadar sürecin içerisinde olmayan insanları kısa bir süre etkilese de, kendi iç gruplarına yönelik olmadıkça ve kendi yaşamlarını tehdit etmedikçe insanları çok da fazla harekete geçirmemektedir.

\section{Örnek Film Analizi}

Filmde sosyal hizmet bağlamında değerlendirilebilecek pek çok yön bulunmaktadır. İlk olarak farklı grup üyelerinin birbirine karşı ne denli tehlikeli eylemlere geçebileceği, olabildiğince etkileyici boyutları ile dikkat çekmektedir. Dillenberger ve Raymond (2016: 24)'ın ifade ettiği gibi groupshift (grup değişimi: grup içerisinde daha yıkıcı hale gelme) kavramının adeta uygulamaya dökülmüş haliyle, grup üyelerinin grup sürecinin ilerleyen aşamalarında çok daha yıkıcı hale gelebildiği rahatılıkla görülebilmektedir. Friedkin (1999: 856)' e göre, bu tür farklılaştırılmalar, kaynakların da giderek azalması ile birlikte grup içinde değişmelere sebebiyet vermekte ve tarafları kutuplaşarak daha yıkıcı hale getirebilmektedir.

Filmde, Muzafer Sherif (2010)' in realistik çatışma kuramına yönelik pek çok örneği bulmak mümkündür. Örneğin, ayrıştırılan grupların ilk olarak karşıt grubu tehdit olarak algılaması, buradan hareketle başlangıçta sembolik tehditlerin oluşturulması daha sonra ise tehditlerin cana kast edebilecek boyutta realistik tehditlere dönüşmesi söz konusudur. Örneğin, filmde ırkları birbirinden ayırt edecek metaforik kavramlar kullanılmaktadır. Hutu'ların, Tutsi'ler için sürekli hamamböceği benzetmesinde bulunması, radyodan yapılan yayınlarla insanların gruplar halinde harekete geçirilmesi ve sürecin sonucunda palalarla yapılan katliamlar göze çarpmaktadır. 
Filmde yapay şekilde oluşturulan ırklar arası nefretin boyutları ve ayrımcılığın kolektif boyutta nerelere varabileceğini dramatik boyutlarıyla görmek mümkündür. Filmde Hutu'lar ve Tutsi'ler arasında karışmış aileler, komşular, akrabalar olduğu halde sadece karşıt gruplardan oldukları için insanların yıkıcı boyuta varabilen radikalleşmelerini görmek oldukça sarsıcıdır.

Filmde sözde karşıt ırk üyelerinin sadece Hutu ya da Tutsi olmalarından dolayı bireysel olarak tehdit altında olduğu görülmektedir. Ayrıca kolektif narsisizme varacak boyutta gerçekçi olmayan inançların olması ve bunun sonucunda ait olunan grubun imajına yönelik bir tehdit hissedildiğinde dış gruba yönelik olumsuz tutumların boyutlarını görmek de mümkündür.

Filmin genelinde işlenen ve vurgulanan nokta ırkçıı̆ın etkisi altındaki grup karşıtıı̆ının ne tür yıkıcı sonuçlara ulaşabileceğinin görülmesidir. Suni şekilde oluşturulmuş karşıt ırka yönelik şiddetin çocuk-yetişkin ayırt etmeksizin binlerce insanı sırf diğer gruptan olmalarından dolayı acımasızca katletmesi boyutuna varabileceğini görmek sarsıcıdır. Sonuç olarak 'Hotel Ruanda' filmi etkileyici sahneleriyle, ırkçılığın ve ayrımcılığın kolektif boyutlarda ne denli tehlikeli sonuçlara varabileceğini görmeyi mümkün kılmaktadır.

Sosyal hizmet uzmanları ırkların olmadığı bir dünyada ırkçılığın tüm yıkıcılığıyla var olduğunun farkında olması gerekmektedir. Teoriden pratiğe baskı altındaki tüm müracaatçılar gibi ırkçılık mağduru müracaatçılar da çalışma öznelerimizi oluşturmaktadır. Bu noktada filmin sosyal hizmet uzmanları tarafından 'sosyal hizmet, ırkçılık ve insanın değeri’ teması ön plana alınarak izlenmesi önerilmektedir.

\section{Değerlendirme, Sonuç ve Öneriler}

Yukarıda yer verilen bilgilerden hareketle, sosyal hizmet ilk uygulamalarından bugüne ırkları ve ırk ayrımcııı̆ını reddeden bir bakış açısına sahiptir. Irkların kurgusal olarak ortaya çıktığının yani ırkların var olmadığının, buna karşın ırkçılığın var olduğunun bilincindedir. Sosyal hizmet her ne kadar ırka dayalı ayrımı reddetse de gerçekleştirilen sosyal hizmet çalışmalarında farklılığa, etnik çeşitliliğe ve kültürel yetkinliğe yönelik kapsayıcı bir çerçeve çizilmesi ihtiyacı bulunmaktadır (Uzunaslan ve Gökçearslan Çifci, 2019: 228). Söz konusu farklılık ve çeşitliliğin korunması, desteklenmesi ve sürdürülmesi sosyal hizmetin savunuculuk faaliyetlerinin doğal bir çıktısı niteliğindedir. Buna karşın bu tür çalışmaların inmal edildiğini hatta bu inmalin bir gelenek haline geldiğini söylemek zor olmayacaktır (Thompson, 2014: 200; 
Thompson 2016: 117). Gerek dünyanın dört bir yanında gerekse de Türkiye'de (Ünlü, 2014: 75), ırkçılık değişen boyutlarda etkisini sürdürmektedir. Bu anlamda sosyal hizmet araştırmalarının ilgili alana yönelmesi bir ihtiyaç olmaktan öte zorunluluk olarak görülmektedir. Çünkü ırkçılık mağduru olan birey, grup ve toplulukların ırkçılığa maruz kalmalarına sebep olan farklılıklarının sürdürülmesinin teminatı ancak yaşanılan ülkedeki politikaların kapsayıcılığı ile söz konusu olabilir. Bu anlamda sosyal hizmet, ırkçılık mağduru insanlar ile yönetsel erk arasındaki bağın kurulması anlamında rol ve sorumluluklara sahiptir. Bu hak savunuculuğu bahsi geçen bireylerin korunmasından öte farklılıklarının ve 'ötekileştirilen' grupların varoluşlarının yüksek sesle dile getirilmesi ile olur. Bahsi geçen farklılıkların örtülmesi yerine dillendirilmesi, var oluşun kanıksanması açısından oldukça önemli görülmektedir. Bu savunuculuk süreci temel eğitim sürecinden sistemsel dönüşüme geniş bir yelpazede, uzun soluklu bir çalışma sürecine intiyaç duymaktadır.

Irkçılık karşıtı sosyal hizmetin birey, grup ve topluluklara yönelik sürdürülen çalışmalarının yanında uygulamadaki hedeflerinin önemli bir ayağını ise toplum çalışmalarının oluşturduğu düşünülmektedir. Bu bağlamda toplumu oluşturan farklı topluluklara ait üyelerin birbiriyle olan yakın ilişkisi, tanımamadan kaynaklanan önyargıların ortadan kaldırıması anlamında önemli bir etkiye sahiptir (Çuhadar Gürkaynak, 2012: 255). Irkçılık karşıtı toplum çalışmaları günlük dilde kullanılan baskıcı ve ayrımcı dilden, sosyal yapıdaki ırkçılığa fırsat tanıyan uygulamalara değin geniş çerçevede çalışmalar yürüten bir makro uygulama alanıdır. Bu uygulama boyutu toplumsal düzlemde çalışmalar gerçekleştirerek eş zamanlı olarak bireysel yaşamları etkilemeyi de amaç edinen bütüncül bir yapı ortaya koyar (Arshad, 1996: 155; Dominelli, 2017: 206). Irkçılığa maruz kalma riski olan azınlık topluluklarına mensup bireylerin başat toplumla ilişki kurması toplumsallaşmanın başladığı ilk dönemlerden itibaren gerçekleşir. Ancak başat toplum üyelerinin azınlık topluluklarına mensup bireylerle ilişki kurması diğeri kadar olası değildir (Tek, 2018: 202). Bu anlamda tanımamanın ortaya çıkarabileceği ayrımcılık, ötekileştirme ve kalıp yargıların ortadan kaldırımasının en önemli yolu 'pozitif temas' olarak görülmektedir. Çayır (2012: 10) çalışmasında temasın başat toplulukların gücü elinde bulundurması ile yarattığı kalıpları ortadan kaldıran bir yönü olduğunu belirtmekte, son yıllarda yaşanan toplumsal dönüşümle birlikte Türkiye'de 'bir araya gelmez' denilen pek çok grubun temas etmeye başladığını ve durumun da ayrımcılığın önüne geçmek adına oldukça önemli bir fırsat olduğunu ifade etmektedir. Buna karşın Aronson ve diğ., (2012: 803) ise temasın her durumda önyargı ve ayrımcılığı azaltmadığını, bunun için 
bazı koşullara intiyaç duyulduğunu ifade etmektedir. Bu koşullar: karşılıklı bağımlılık, ortak amaç, eşit statü, kişilerarası içten bir temas, birden çok üyeyle temas ve eşitlikle ilgili sosyal norm intiyacıdır. Bu noktada toplumu oluşturan tarafların birbiri ile pozitif bir temasla ilişkiselliğinin sağlanması, ortak bir amaç için buluşturulması ve söz konusu süreçlerde benzer statülerde olmaları önem arz etmektedir. Böyle bir ortamın sağlanmasında sosyal hizmetin alan uygulamalarında öncül olabileceği düşünülmektedir.

Sosyal hizmet uzmanlarının ırkçılık karşıtı ve kültürel açıdan yetkin bir eğitim sürecinden geçmesi oldukça önemlidir. Lisans sürecinde alınan eğitimde sosyal hizmetin ırkçılık karşıtı yapısının özellikle vurgulanması gerekmektedir. Öğrencilere sahip olabilecekleri potansiyel ırkçılığın keşfi için destek verilmesi ve eleştirel bakış açısının kazandırılması hedeflenmelidir (Hoyt Jr, 2012: 232-234). Eğitim sürecinde yaşanılan ülkede yer alan farklı etnik ve kültürel toplulukların yaşamları, özellikleri ve hassasiyetleri derinlemesine tartışılmalıdır. Böylelikle eğitim sürecinde çeşitlilik vurgusu ile kültürel yetkinliğini geliştirmiş olan sosyal hizmet uzmanlarının alanda karşılaşabileceği 'öteki' müracaatçı gruplarına yönelik bilgi ve öngörü sahibi olması sağlanacaktır.

Sonuç olarak, günümüzde ırkçılığın modern dünya sisteminin fikri anlamda dayanaklarından birini oluşturduğu, bu yolla da toplumsal açıdan mağdur olan grupların haklarını savunmalarının güçleştiği ifade edilmektedir (Güldalı, 2017: 233). $\mathrm{Bu}$ anlamda sosyal hizmetin gerek bilimsel gerekse de mesleki misyonu ile kısa vadede ırkçılık mağdurlarının haklarının temini ve savunulması konularında, uzun vadede ise koruyucu- önleyici çalışmaları ile toplumsal düzeyde ırkçılığın tamamen ortadan kaldırımasını amaçlayan çalışmalar gerçekleştirmesinin gerekli olduğu düşünülmektedir.

\section{KAYNAKÇA}

Acar H, İçağasıoğlu Çoban A, Polat G. (2017). Sosyal hizmetlerde yanlış uygulamalar, etik ihlaller ve sorunlara ilişkin bir araştırma. Ankara: Türkiye Felsefe Kurumu.

Aronson, E., Wilson, T. D., \& Akert, R. M. (2012). Social psychology Pearson Higher Ed.Balibar, E., Wallerstein, I. M., \& Wallerstein, S. R. I. (1991). Race, nation, class: Ambiguous identities. Verso.

Arshad, R. (1996). Anti-racist community work-a radical approach. Radical Community Work, 150-169.

Banton, M. (1969). What do we mean by racism. New Society, 13(341), 551-554. 
Brockmann, M., Butt, J., and Fisher, M. (2001). The experience of racism: black staff in social services. Research, Policy and Planning, 19(2).

Bulmer, M. and Solomos, J. (1999). Racism. Oxford: Oxford University Press.

Butler, A., Elliott, T. and Stopard, N. (2003). Living up to the standards we set: a critical account of the development of anti-racist standards. Social Work Education, 22(3).

Büyükbay, C. (2016). Barış karşıtı ideolojiler: ırkçılık ve köktendincilik. Toplumcu düşünce enstitüsü değerlendirme notu 16(02).

Center for Health Workforce Studies and National Association of Social Workers (2006). Licensed social workers in the U.S. 2004, Vol. 2 (Supplement). Washington, DC: Author. Retrieved from https://www.socialworkers.org/LinkClick.aspx?fileticket=mV QzNOaDzc\%3D\&portali $\underline{\mathrm{d}=0}$

Chou, C. C. (2008). Critique on the notion of model minority: an alternative racism to Asian American?. Asian Ethnicity, 9(3), 219-229.

Çayır, K. (2012). Gruplararası ilişkiler bağlamında ayrımcılık. K.Çayır ve M. Ayan Ceyhan (Ed). Ayrımcılık çok boyutlu yaklaşımlar (5-17). İstanbul Bilgi Üniversitesi Yayınları: İstanbul.

Çuhadar Gürkaynak, E. (2012). Toplumsal temas: önyargı ve ayrımcılığı önlemek için bir sosyal değişim aracı olarak kullanılabilir mi? K.Çayır ve M. Ayan Ceyhan (Ed). Ayrımcılık çok boyutlu yaklaşımlar (255-266). İstanbul Bilgi Üniversitesi Yayınları: İstanbul.

De Montigny, G. A. (2013). The essentialism of whiteness: Abandoning empirical engagement. Journal of Social Work, 13(6), 633-651.

Desai, S. and Gooden, M. (1995). Anti- racist social work: a case example of work with and African Caribbean family. Child Abuse Review. (4).

Dillenberger, D., and Raymond, C. (2016). Group-Shift and the Consensus Effect, Second Version (No. 16-015). Penn Institute for Economic Research, Department of Economics, University of Pennsylvania.

Dominelli, L. (2017). Anti-racist social work. Macmillan International Higher Education.

Eliassi, B. (2017). Conceptions of immigrant integration and racism among social workers in sweden. Journal of progressive human services, 28(1), 6-35.

Friedkin, N. E. (1999). Choice shift and group polarization. American Sociological Review, 856-875.

Friedman, I. R. (1995). The other victims of the Nazis. Social Education, 59(6), 339-410.

George-Bettisworth, R. (2017). The quest for inclusive cultural competence in social work education. (Doctoral dissertation, St. Catherine University).

Giddens, A. (2008). Sosyoloji, ırk, etniklik, göç. İstanbul: Kırmızı Yayınları.

Graham, M. (2000). Honouring social work principles- exploring the connections between antiracist social work and African- centered worldviews. Social Work Education Journal. 19(5).

Grosfoguel, R. (2013). The structure of knowledge in westernized universities: Epistemic racism/sexism and the four genocides/epistemicides of the long 16th century. Human Architecture: Journal of the sociology of self-knowledge, 11(1), 8.

Grosfoguel, R., Oso, L., and Christou, A. (2015). 'Racism', intersectionality and migration studies: framing some theoretical reflections. Identities, 22(6), 635-652. 
Grosfoguel, R. (2016). What is racism?. Journal of World-Systems Research, 22(1), 9-15.

Güldalı, O. (2017). Baskı karşıtı sosyal hizmet: modern dünya-sistemi açısından eleştirel bir değerlendirme. Toplum ve Sosyal Hizmet, 29(1), 229-245.

Güvenç, B. (2016). İnsan ve kültür. Boyut Yayın Grubu: İstanbul.

Hoyt Jr, C. (2012). The pedagogy of the meaning of racism: Reconciling a discordant discourse. Social work, 57(3), 225-234.

Hughes, D. (2012). Blackness in Gobineau and Behn: Oroonoko and Racial PseudoScience. Women's writing, 19(2).

Keating, F. (2000). Anti racist perspectives: what are the gains for social work? Social Work Education Journal. 19(1).

Kongar, E. (2007). Sosyal çalışmaya giriş. Sosyal Bilimler Derneği Yayınları: G-2'den Tıpkıbasım Sabev Yayınları: Ankara.

Laird, S. E. (2008). Anti-oppressive social work. Sage Publications: London.

Lopez, I. F. H. (2000). The social construction of race (pp. 964-974). na.

Loya, M. (2011). Color-blind racial attitudes in white social workers: A cross-sectional study. Smith College Studies in Social Work, 81(2-3), 201-217.

Marks, J. (2008). Race: past, present, and future. In B. A. Koenig, S. S. Lee \& S. S. Richardson (eds.), Revisiting race in a genomic age (pp. 21-38). New Jersey: Rutgers University Press.

McPherson, J. (2015). Human rights practice in social work: A rights-based framework \& two new measures (Doctoral dissertation, The Florida State University).

Özbek, S. (2012). Irkçılık. Notos Kitap: İstanbul.

Özgür, Ö. (2014). Çokkültürcü sosyal çalışma. Sabev Yayınları: Ankara.

Rattansi, A. (1994). Western racisms, ethnicities and Identities. In, A. Rattansi and S. Westwood (eds.) Racism, Modernity and Identity on the Western Front. Cambridge. Polity.

Rubiés, J. P. (2013). Race, climate and civilization in the works of François Bernier. Purusārtha, (31), 53-78.

Sayın, E. ve Candan, H. (2016). Küresel ırkçılı̆ı̆ın yükselişi. Ardahan Üniversitesi Iktisadi ve Idari Bilimler Fakültesi Dergisi. 4, 35-46.

Sherif, M. (2010). The robbers cave experiment: Intergroup conflict and cooperation.[Orig. pub. as Intergroup conflict and group relations]. Wesleyan University Press.

Somersan, S. (2009). Irkların olmadığı bir dünyada ırkçılık. İstanbul Bilgi Üniversitesi Sosyoloji ve Eğitim Çalışmaları, Birimi Yayınları: İstanbuı.

Stuurman, S. (2000). François Bernier and the invention of racial classification. In History Workshop Journal. 50(1), 1-21. Oxford University Press.

Tek, S. (2018). Azınlıklarla sosyal hizmet: Türkiye'de yaşayan azınlıkların toplumsallaşma deneyimleri ve sosyal politika gereksinimleri. (Yayınlanmamış Doktora Tezi, Hacettepe Üniversitesi Sosyal Bilimler Enstitüsü).

Thompson, N. (2006). Anti-discriminatory practice. Palgrave Macmillan: Basingstoke.

Thompson, N. (2014). Anti-discriminatory practice (4th ed.). Palgrave Macmillan: London. 
Thompson, N. (2016). Anti-discriminatory practice: equality, diversity and social justice. Macmillan International Higher Education.

Traoré, M. (2010). One story of academia: race lines and the rhetoric of distinction through the académie française (Vol. 176). Peter Lang.

Uzunaslan, Ş. ve Gökçearslan Çifçi, E. (2019). Sosyal hizmet uygulamalarında kültürel yetkinliği geliştirmenin önemi. Toplum ve Sosyal Hizmet, 30(1), 213-230.

Ünlü, B. (2014). Türklük sözleşmesi'nin imzalanışı (1915-1925). Mülkiye Dergisi, 38(3), 47-82.

Wainwright, J. (2009). Racism, anti-racist practice and social work: articulating the teaching and learning experiences of black social workers. Race Ethnicity and Education, 12 (4), 495-512. 